\title{
PROBLEMATIKA PENYELESAIAN SENGKETA TANAH DI LOKASI TANJ UNG SARI KABUPATEN BANGGAI
}

\author{
Nasrun Hipan ${ }^{1}$, Nirwan Moh Nur², Hardianto Djanggih ${ }^{3}$ \\ 1Fakultas Hukum Universitas Muhammadiyah Luwuk Banggai \\ J alan K.H. Ahmad Dahlan No 79 luwuk, Kabupaten Banggai, Sulawesi Tengah \\ 2Fakultas Hukum Universitas Tompotika Luwuk Banggai \\ J alan Dewi Sartika No. 67 Luwuk-Banggai, Sulawesi Tengah \\ hardianto.djanggih@gmail.com
}

\begin{abstract}
This study aims to analyze land dispute resolution at Tanjung Sari Location in Banggai Regency. The status of the land has taken a long and very complicated legal process and caused uncertainty for the parties to the dispute. The research method used is a sociological juridical research method that is examining the law based on social phenomena. The results of the research show that the land dispute at Tanjung Sari Location in Banggai Regency, which starts from the court process gradually until the court decision is executed, there is a difference or disputes between the parties who are against the land object. The land dispute which has been going on for quite a long time will have an impact on the uncertainty of land tenure rights by the parties to the dispute if it is not resolved by the right law.
\end{abstract}

Keywords: Dispute Resolution; Land; Tanjung Sari.

\begin{abstract}
ABSTRAK
Penelitian ini bertujuan untuk menganalisis penyelesaian sengketa tanah di Lokasi Tanjung Sari Kabupaten Banggai, Adapun status tanah tersebut telah menempuh proses hukum yang panjang dan sangat rumit dan mengakibatkan ketidakpastian bagi pihak yang bersengketa. Adapun metode penelitian yang digunakan adalah metode penelitian yuridis sosiologis yakni mengkaji hukum berdasarkan fenomena-fenomenas sosial. Hasil penelitian menunjukkan bahwa sengketa tanah di Lokasi Tanjung Sari Kabupaten Banggai yang dimulai dari proses pengadilan secara bertahap sampai pada ekseusi putusan pengadilan terjadi perbedaan atau perselidihan antara pihak-pihak yang berpekara terhadap objek tanah tersebut. Sengketa tanah tersebut yang telah berjalan cukup panjang akan berdampak pada ketidakpastian hak penguasaan atas tanah oleh pihak-pihak yang bersengketa jika tidak diselesaikan dengan hukum yang tepat.
\end{abstract}

Kata Kunci: Penyelesaian Sengketa; Tanah; Tanjung Sari.

\footnotetext{
${ }^{1}$ Dosen Program Studi Ilmu Hukum Universitas Muhammadiyah Luwuk Banggai

2 Dosen Program Studi IImu Hukum Universitas Muhammadiyah Luwuk Banggai

3 Penulis Koresponden, Dosen Program Studi IImu Hukum Universitas Tompotika Luwuk Banggai
} 


\section{Pendahuluan}

Manusia hidup serta melakukan aktivitas di atas tanah sehingga setiap saat manusia selalu berhubungan dengan tanah. Dapat dikatakan hampir semua kegiatan hidup manusia baik secara langsung maupun tidak langsung selalu memerlukan tanah (Arisaputra, 2013). Nilai ekonomis, nilai sosial dan nilai budaya yang dimiliki tanah menjadikan tanah sebagai sumber kehidupan ekonomi manusia (Asikin, 2014). Hal ini tidak terlepas dari adanya fungsi ganda terhadap tanah, yaitu sebagai social asset dan capital asset, sehingganya kehidupan manusia tidak dapat dipisahkan dari tanah (Permatasari, et.all, 2018).

Kebutuhan akan tanah dewasa ini dengan bertambahnya jumlah penduduk, mengakibatkan terbatasnya jumlah tanah untuk dijadikan sebagai sumber penghasilan dan tempat tinggal, maka orang perlu untuk mendapatkan suatu jaminan akan kepastian hukum dan perlindungan hukum terhadap hak kepemilikan atas tanah (Hidayat, 2016).

Dalam pemenuhan kebutuhan tanah, seringkali terdapat Permasalahan-permasalahan yang berorientasi pada terciptanya kepastian hukum tentang letak dan luas tanah, jenis hak atas tanah serta besarnya uang ganti kerugian (Djanggih, 2017). Semakin meningkatnya pertumbuhan penduduk, maka kebutuhan akan ketersediaan tanah menjadi semakin tinggi pula. Dalam perkembangannya, kebutuhan terhadap tanah telah memunculkan berbagai konflik/sengketa, baik antar perorangan maupun suatu kelompok terkait.

Sengketa pertanahan merupakan perbedaan nilai, kepentingan, pendapat dan suatu persepsi antara orang perseorangan dan antara badan hukum (privat dan publik) mengenai status penguasaan dan atau status kepemilikan dan atau status penggunaan atau pemanfaatan atas bidang tanah tertentu oleh pihak tertentu, atau status keputusan Tata Usaha Negara menyangkut penguasaan, pemilikan dan penggunaan atau pemanfaatan atas bidang tanah tertentu (Panget, 2013).

Sengketa Pertanahan di Indonesia bukan merupakan hal yang baru dan masih terjadi hingga saat ini (Wowor, 2014). Dalam penelitiannya (Wowor, 2014) mengungkap bahwa berbagai penyelesaian terhadap sengketa pertanahan dapat dilakukan melalui dua cara, yaitu: (1) Penyelesaian Sengketa Melalui Jalur Pengadilan, dan; (2) Penyelesaian Sengketa Melalui Alternative Dispute Resolution (ADR).

Kaitannya dengan permasalahan sengketa tanah sebagai objek kajian di Lokasi Tanjung Sari adalah mengkaji permasalahan tanah berdasarkan putusan pengadilan. Sengekta tanah tersebut bermula dari adanya Gugatan Sdr. Pintung, Dkk (Penggugat / Kuasa Hadin Lanusu), terhadap Husen Taferokila (Tergugat) tertanggal 9 Januari 1996, Registrasi Perkara Perdata, Nomor: 02/PDT/G/ 1996/PN.Lwk, telah menempatkan objek sengketa berupa 2 (dua) bidang tanah yang tengah dikuasai oleh Tergugat. 
Ahli Waris Salim Al Bakkar, yaitu Ny. Berkah Albakkar pada tanggal 4 Juni 1996 telah mengajukan Gugatan Intervensi yang berdiri sendiri (tussenkomst), sehingga telah menempatkan Para Penggugat / Kuasa Hadin Lanusu serta Husen Taferokila (Tergugat), masing-masing sebagai Para Tergugat Intervensi.

Sehingganya menarik bagi penulis untuk mengkaji lebih jauh tentang problematika penyelesaian sengketa tanah di Lokasi Tanjung Sari di Kabupaten Banggai.

\section{Metode Penelitian}

Penelitian ini adalah bersifat deskriptif analitis. Jenis penelitian ini adalah penelitian hukum normatif, yaitu penelitian dilakukan dengan cara menganalisis hukum yang tertulis dari bahan pustaka atau data sekunder, yang menjadi bahan acuan kajian ini. Data sekunder yang telah dikumpulkan melalui studi dokumen terhadap bahan kepustakaan antara lain meliputi bahan hukum primer seperti peraturan perundangundangan dan putusan pengadilan.

Dalam penelitian ini pengkajian bahan hukum dilakukan secara mendalam terhadap putusan pengadilan dan pelaksanaan putusan pengadilan terkait dengan objek sengketa tanah yang di hubungan dengan norma hukum, konsep hukum teori hukum, yang relevansinya dengan permasalahan. Penelitian hukum dilakukan untuk mencari pemecahan terhadap isu hukum yang timbul. Hasil yang aka dicapai adalah memberikan preskripsi tentang apa yang seyogyanya atas isu yang mengemuka. Analisis dilakukan secara kualitatif, baik dengan mengedepankan prinsip-prinsip hukum maupun menganalisis factor-faktor lain yang mempengaruhi substansi dan prosedural penyelesaian kasus tanah.

\section{Pembahasan}

\subsection{Kerangka Konseptual}

Sebagai kajian ini adalah mengkaji sengketa tanah atas putusan pengadilan. Putusan pengadilan adalah keputusan pengadilan atas perkara gugatan berdasarkan adanya suatau sengketa. Berbeda dengan penetapan yang yang diambil oleh hakim apabila perkaranya adalah permohonan di mana kekuatan penetapannya bersifat deklaratoir, putusan diambil oleh hakim apabila perkaranya berupa sutau sengketa di mana para pihak saling mempertahankan hak masingmasing. Jadi perkaranya diperiksa secara contradictoir (timbal balik), sehingga putusannya bersifat comdemnatoir (menghukum) pihak yang kalah (Rasyid, 2010).

Secara umum putusan pengadilan diatur dalam Pasal 185 HIR, Pasal 196 RBG, dan Pasal 46-68 Rv. Dapat dikemukakan berbagai segi putusan pengadilan yang dapat dijatuhukan hakim, namun dalam uraian ini hanya diuraikan jenis putusan yang berhubungan dengan kajian ini.

\section{a. Putusan Declaratoir (pernyataan)}

Putusan declaratoir adalah putusan yang hanya menegaskan atau menyatakan suatu kedaan hukum semata-mata. Misalnya putusan 
tentang keabsahan anak angkat menurut hukum, putusan ahli waris yang sah (Harahap, 2011).

b. Putusan Preparatoir

Putusan preparatoir adalah putusan sebagai akhir yang tanpa ada pengaruh terhadap pokok perkara atau putusan akhir. Misalnya: putusan yang untuk menggabungkan dua perkara atau untuk menolak diundurkannya pemeriksaan saksi, putusan yang memerintahkan pihak yang diwakili oleh kuasanya untuk datang sendiri (Mujahidin, 2012).

\section{c. Putusan Kontradiktoir}

Putusan kontradiktoir adalah putusan yang diambil dari tergugat yang perna datang menghadap di persidangan, tetapi pada hari-hari sidang berikutnya tidak datang maka perkaranya diperiksa secara kontradiktor, kemudian diputuskannya. Artinya, diputus di luar hadirnya salah satu pihak yang berperkara (Mujahidin, 2012).

\section{d. Putusan Akhir}

Setelah hakim selesai memeriksa perkara dan tidak ada lagi halhal yang perlu diselesaikan dalam persidangan, maka hakim menjatukan putusan terhadap perkara yang diperiksanya. Putusan akhir adalah suatu pernyataan yang oleh hakim, sebagi pejabat negara yang diberi wewenang untuk itu, diucapkan dalam persidangan dan bertujuan untuk mengakhiri atau menyelesaikan perkara atau sengketa antara para pihak yang beperkara dan diajukan kepada pengadilan (Winarta, 1995)

\subsection{Objek Sengketa Tanah Lokasi Tanjung Sari Kabupaten Banggai}

Tanah merupakan aset yang bernilai tinggi. Pertambahan jumlah penduduk berbanding terbalik dengan tidak bertambahnya luas tanah, sehingga memungkinkan setiap orang berupaya untuk menguasasi tanah (Ismail, 2017). Sementara tuntutan akan lahan merupakan konsekwensi dari kegiatan pembangunan fisik yang memerlukan tanah sebagai sarananya (Pangemanan, 2013). Permasalahan terhadap tanah, sebuah masalah yang "menggurita" seakan-akan tidak dapat diselesaikan dengan baik. Konflik terjadi karena adanya kebutuhan akan tanah untuk tujuan tertentu meningkat (Listyawati, 2010).

Kaitannya dengan hal tersebut, terhadap kasus tanah di Lokasi Tanjung Sari Kabupaten Banggai yang menjadi objek sengketa perkara pokok adalah merupakan bagian dari tanah milik Penggugat Intervensi yang berukuran luas \pm 6 $\mathrm{Ha}$, dengan batas-batas:

- Utara dahulu berbatasan dengan teluk Luwuk, sekarang berbatasan dengan tanah Pemerintah Daerah dan Kompleks Dolog;

- Timur, dahulu berbatasan dengan tanahnya Pr. Maasing dan Pr. Keling, sekarang berbatasan dengan tanah I Lamusa;

- Selatan dahulu berbatasan dengan jurame, sekarang dengan jurang;

- Barat, berbatasan dengan kebunnya Pandan dan Hutan Lolaro; 
Adapun asal usul pemilikan tanah Salim Albakkar, diperoleh dengan cara sebagai berikut:

- Bahwa semula hamparan tanah kebun yang diatasnya terdapat 205 pohon kelapa yang terletak di Tanjung semula disebut Tumbu adalah milik Sech Saleh Bin Hasan Al Amri. Selanjutnya Sech Saleh Bin Hasan Al Amri menjual hamparan tanah berikut tanaman kelapa diatasnya kepada Kalia - Sangaji (Camat). Penjualan tersebut dibuktikan dengan adanya Surat Penjualan tanpa tanggal, bulan dan tahun;

- Dengan telah terjadinya penjualan tersebut maka Kalia-Sangaji menjual kembali hamparan tanah beserta tanaman kelapa diatasnya sejumlah 174 pohon kepada $\mathrm{H}$. Husin alias Dg. Maloe, sebagaimana termuat dalam Surat Penjualan tanggal 22 Maret 1914;

- Bahwa ketika H. Husin alias Dg. Maloe meninggal dunia, maka pemilikan lahan serta kebun kelapa tersebut dilanjutkan oleh saudaranya yang bernama $H$. Muhammad Nur. Selanjutnya H. Muhammad Nur menjual lahan serta pohon kelapa tersebut kepada $\mathrm{H}$. Abdul Wahid, sebagaimana termuat dalam Surat Penjualan bertanggal 12 Februari 1922;

- Bahwa oleh karena H. Abd. Wahid mempunyai hutang dagang kepada Salim Al Bakkar, dan untuk menyelesaikan hutang dagang tersebut maka H. Abdul Wahid telah menyerahkan lahan kebun beserta 395 pohon kelapa kepada Salim Al Bakkar, pada Tahun 1938. Selanjutnya hamparan tanah perkebunan berikut 395 pohon kelapa adalah menjadi milik Salim Al Bakkar.

Bahwa sesuai dengan hasil pemeriksaan persidangan, maka oleh Majelis Hakim Pengadilan Negeri Luwuk, telah menjatuhkan Putusan Pengadilan Negeri Luwuk, Nomor :02/Pdt.G/1996/PN.Lwk, tanggal 9 Juli 1996, yang amar putusannya adalah sebagai berikut :

\section{DALAM EKSEPSI}

- Menolak Eksepsi B (Tergugat dalam Pokok Perkara);

- Menolak Eksepsi A (Penggugat dalam Pokok Perkara / Tergugat Intervensi;

\section{DALAM POKOK PERKARA}

- Menolak Gugatan A (Penggugat dalam Pokok Perkara / Tergugat Intervensi seluruhnya;

\section{DALAM GUGATAN INTERVENSI}

- Mengabulkan Gugatan C (Penggugat Intervensi) tersebut;

- Meneguhkan Hak Milik C (Intervenient) atas tanah yang tengah diperkarakan oleh A (Penggugat dalam Pokok Perkara dan B (Tergugat dalam Pokok Perkara) sebagai dimaksud dalam Gugatan Perkara Perdata, Nomor: 02/Pdt.G/1996/PN.Lwk ;

Mendasari Putusan Pengadilan Negeri Luwuk, Nomor :02/Pdt.G/1996/PN.Lwk, tanggal 9 Juli 1996, oleh Penggugat dalam Pokok Perkara (Tergugat Intervensi) telah mengajukan Banding ke Pengadilan Tinggi Sulawesi Tengah. Oleh Pengadilan Tinggi Sulawesi Tengah melalui Putusan Pengadilan Tinggi Sulawesi Tengah, 
Nomor : 81/PDT/1996/PT.Palu, tanggal 15 Januari 1997, telah menjatuhkan Putusan ; Menguatkan Putusan Pengadilan Negeri Luwuk, Nomor :02/Pdt.G/1996/PN.Lwk, tanggal 9 Juli 1996.

Terhadap Putusan Pengadilan Negeri Luwuk tersebut diketahui secara jelas bahwa objek Gugatan dalam Perkara Perdata Nomor: 02/Pdt.G/1996 (termasuk Gugatan Intervensi) adalah meliputi 2 (dua) bidang tanah sesuai ukuran dan batas-batas yang telah disebutkan di atas, hal mana melalui kedua putusan pengadilan tersebut telah dinyatakan (diteguhkan) sebagai milik Penggugat Intervensi in casu Salim Al Bakkar.

Lebih lanjut Putusan Pengadilan Tinggi Sulawesi Tengah, Nomor: 81/PDT/1996/PT.Palu, tanggal 15 Januari 1997 oleh Penggugat dalam perkara pokok (Tergugat Intervensi) telah mengajukan Kasasi kepada Mahkamah Agung Republik Indonesia. Atas permohonan tersebut maka Mahkamah Agung Republik Indonesia telah menjatuhkan Putusan Mahkamah Agung, Nomor : 2351 K/Pdt.1997, tanggal 02 Juni 1999, yang amar putusannya adalah menolak Permohonan Kasasi dari para pemohon kasasi : 1. HADIN LANUSU, 2. PINTUNG, 3. BAHRUN LANUSU, 4. MASNIA LANUSU, 5. MIN LANUSU, tersebut dan memperbaiki amar Putusan Pengadilan Tinggi Palu tanggal 15 Januari 1997 No. 81/Pdt/1996/PT.Palu, yang menguatkan Putusan Pengadilan Negeri Luwuk tanggal 09 Juli 1996 Nomor : 02/Pdt.G/1996/PN.Lwk.
Putusan Mahkamah Agung, Nomor : 2351 K/Pdt.1997, tanggal 02 Juni 1999, oleh Para Penggugat / Pembanding / Pemohon Kasasi/Para Tergugat Intervensi telah mengajukan Permohonan Peninjauan Kembali kepada Mahkamah Agung Republik Indonesia. Oleh Majelis Hakim Peninjauan Kembali telah menjatuhkan Putusan Peninjauan Kembali Nomor: 655 PK/Pdt/2000, tanggal 13 Oktober 2003, yang amar putusannya adalah menolak Permohonan Peninjauan Kembali dari para Pemohon Peninjauan Kembali : HADIN LANUSU yang bertindak untuk diri sendiri dan selaku kuasa dari : 1. PINTUNG, 2. BAHRUN LANUSU, 3. MASNIA LANUSU, 4. MIN LANUSU tersebut.

Objek sengketa jika mendasari Putusan Pengadilan Negeri Luwuk, Nomor :02/Pdt.G/1996/PN.Lwk, tanggal 9 Juli 1996 Jo. Putusan Pengadilan Tinggi Sulawesi Tengah, Nomor: 81/PDT/1996/PT.Palu, tanggal 15 Januari 1997, selain kedua putusan itu bersifat declaratoir, juga objek sengketa (tanah sengketa) yang dimaksudkan dalam Gugatan Intervensi hanyalah mengikuti atau sesuai dengan objek sengketa dalam perkara pokok, yaitu 2 (dua) bidang tanah, masing-masing:

Bidang Pertama

Berukuran Panjang 26,50meter dan lebar 22 meter, dengan batas-batas:

- Utara dengan tanahnya Salim Al Bakkar/Wakaf;

- Timur dengan Pintung (Penggugat);

- Selatan dengan tanah Lawae ; 
- Barat dengan Jalan Raya Yos Sudarso;

Bidang Kedua

Berukuran panjang 13,35 meter dan lebar 6,70 meter, dengan batas-batas:

- Utara dengan tanah Salim Albakkar I wakaf;

- Timur dengan rumah kediaman Pintung (Penggugat I) yang didirikan di atas tanah Penggugat;

- Selatan dengan tanah PenggugatPenggugat;

- Barat dengan tanah Objek Perkara;

Sedangkan jika kita memperhatikan secara saksama amar Putusan Mahkamah Agung, Nomor: 2351 K/Pdt.1997, tanggal 02 Juni 1999 maka jelas terlihat bahwa objek sengketa (tanah sengketa) adalah berada dalam batasbatas:

- Utara dahulu berbatasan dengan teluk Luwuk, sekarang berbatasan dengan tanah Pemerintah Daerah dan Kompleks Dolog;

- Timur, dahulu berbatasan dengan tanahnya Pr. Maasing dan Pr. Keling, sekarang berbatasan dengan tanah I Lamusa;

- Selatan dahulu berbatasan dengan jurame, sekarang dengan jurang;

- Barat, berbatasan dengan kebunnya Pandan dan Hutan Lolaro;

Dalam ukuran luas \pm 6 Ha sesuai dalil posita Gugatan Intervensi Penggugat Intervensi, serta dinyatakan sebagai Milik NY. BERKAH ALBAKKAR.
Dengan demikian maka ukuran serta batas-batas bidang tanah (objek sengketa / tanah sengketa) adalah berbeda antara apa yang tertera dalam Putusan Mahkamah Agung, Nomor: 2351 K/Pdt.1997, tanggal 02 Juni 1999, dengan apa yang menjadi objek sengketa dalam Gugatan Intervensi sebagaimana tertuang dalam perkara pokok dan tercantum dalam Putusan Pengadilan Negeri Luwuk, Nomor :02/Pdt.G/1996/PN.Lwk, tanggal 9 Juli 1996 Jo. Putusan Pengadilan Tinggi Sulawesi Tengah, Nomor: 81/PDT/1996/PT.Palu, tanggal 15 Januari 1997.

Terhadap putusan tersebut Kuasa Hukum Ahli Waris Salil Albakkar semula Penggugat Intervensi, masing-masing: Sukirlan Sandagang, S.H. dan Dahlan H. Dani, S.H. telah mengajukan Permohonan Pelaksanaan Putusan (Eksekusi) atas Putusan Pengadilan Negeri Luwuk, Nomor :02/Pdt.G/1996/PN.Lwk, tanggal 9 Juli 1996 Jo. Putusan Pengadilan Tinggi Sulawesi Tengah, Nomor: 81/PDT/1996/PT.Palu, tanggal 15 Januari 1997 Jo. Putusan Mahkamah Agung, Nomor: 2351 K/Pdt.1997, tanggal 02 Juni 1999 Jo. Putusan Peninjauan Kembali Nomor: 655 PK/Pdt/2000, tanggal 13 Oktober 2003 untuk tanah milik Penggugat Intervensi seluas $\pm 6 \mathrm{Ha}$. Atas Permohonan tersebut maka Ketua Pengadilan Negeri Luwuk telah mengeluarkan Penetapan Nomor: 02/Pen.Pdt.G/1996/PN.Lwk, tanggal 14 Nopember 2006, yang isinya adalah bahwa Putusan Pengadilan Negeri Luwuk, Nomor :02/Pdt.G/1996/PN.Lwk, tanggal 9 Juli 1996 Jo. Putusan Pengadilan Tinggi Sulawesi Tengah, 
Nomor: 81/PDT/1996/PT.Palu, tanggal 15 Januari 1997 Jo. Putusan Mahkamah Agung, Nomor: 2351 K/Pdt./1997, tanggal 02 Juni 1999 Jo. Putusan Peninjauan Kembali Nomor: 655 PK/Pdt/2000, tanggal 13 Oktober 2003 adalah NonExecutable (tidak dapat dieksekusi).

Atas Penetapan Ketua Pengadilan Negeri Luwuk tersebut, selanjutnya diajukan Surat Permohonan Pembatalan Penetapan Ketua Pengadilan Negeri Luwuk tersebut yang ditujukan kepada Ketua Pengadilan Tinggi Sulawesi Tengah. Atas Permohonan tersebut maka Ketua Pengadilan Tinggi Sulawesi Tengah melalui Penetapan Nomor: 01/Pen.Pdt/2008/PT.Sulteng, tanggal 21 Agustus 2008 menyatakan: Membatalkan Penetapan Ketua Pengadilan Negeri Luwuk Nomor : 02/Pen.Pdt.G/1996/PN.Lwk, tanggal 14 Nopember 2006, serta memerintahkan Ketua Pengadilan Negeri Luwuk untuk melanjutkan pelaksanaan Putusan Mahkamah Agung, Nomor : 2351 K/Pdt./1997, tanggal 02 Juni 1999 Jo. Putusan Peninjauan Kembali Nomor: 655 PK/Pdt/2000, tanggal 13 Oktober 2003, sepanjang mengenai 2 (dua) bidang tanah yang telah bersifat condemnatoir, terdiri dari :

\section{Bidang Pertama}

Berukuran Panjang 26,50 meter dan lebar 22 meter, dengan batas-batas:

- Utara dengan tanahnya Salim A Bakkar/Wakaf;

- Timur dengan Pintung (Penggugat);

- Selatan dengan tanah Lawae;
- Barat dengan Jalan Raya Yos Sudarso;

\section{Bidang Kedua}

Berukuran panjang 13,35 meter dan lebar 6,70 meter, dengan batas-batas:

- Utara dengan tanah Salim Albakkar I wakaf;

- Timur dengan rumah kediaman Pintung (Penggugat I) yang didirikan di atas tanah Penggugat;

- Selatan dengan tanah PenggugatPenggugat;

- Barat dengan tanah Objek Perkara; Adapun materi Penetapan Nomor: 01/Pen.Pdt/2008/PT.Sulteng, tanggal 21 Agustus 2008 telah tidak ditindaklanjuti oleh Penggugat Intervensi ataupun kuasa hukumnya, sehingga Putusan Mahkamah Agung, Nomor: 2351 K/Pdt./1997, tanggal 02 Juni 1999 Jo. Putusan Peninjauan Kembali Nomor : 655 PK/Pdt/2000, tanggal 13 Oktober 2003 belum dilaksanakan (eksekusi).

Selanjutnya Kuasa Hukum Ahli Waris Salim Albakkar semula Penggugat Intervensi; Mustafa Patiwael, S.H. telah mengajukan Permohonan eksekusi PutusanMahkamah Agung, Nomor: 2351 K/Pdt./1997, tanggal 02 Juni 1999 Jo. Putusan Peninjauan Kembali Nomor : 655 PK/Pdt/2000, tanggal 13 Oktober 2003 untuk tanah (sesuai Putusan Mahkamah Agung Nomor : 2351 K/Pdt./1997), dengan batas-batas :

- Utara dahulu berbatasan dengan teluk Luwuk, sekarang berbatasan dengan tanah Pemerintah Daerah dan Kompleks Dolog; 
- Timur, dahulu berbatasan dengan tanahnya Pr. Maasing dan Pr. Keling, sekarang berbatasan dengan tanah Lamusa;

- Selatan dahulu berbatasan dengan jurame, sekarang dengan jurang;

- Barat, berbatasan dengan kebunnya Pandan dan Hutan Lolaro;

Hal mana sesuai dalil Gugatan Intervensi adalah seluas $\pm 6 \mathrm{Ha}$.

Atas Permohonan tersebut maka oleh Ketua Pengadilan Negeri Luwuk; Nanang Zulkarnain Faisal, S.H. telah mengeluarkan Penetapan Eksekusi lahan sesuai dengan batasbatas yang tercantum dalam Putusan Mahkamah Agung R.I. Selanjutnya oleh Ketua Pengadilan Negeri Luwuk, Ahmad Yani, S.H., M.H. telah melaksanakan Putusan (Eksekusi) tahap pertama, tanggal 3 s.d. 6 Mei 2017. Adapun luas lahan yang dieksekusi adalah $\pm 9 \mathrm{Ha}$, yang dilakukan dengan cara membongkar bangunan rumah milik $134 \mathrm{KK}$. Kemudian pada tanggal 19 s.d. 22 Maret 2018 telah dilakukan Eksekusi lanjutan yang dilakukan dengan cara membongkar bangunan rumah tinggal, sehingga luas lahan yang dieksekusi mencapai $\pm 18 \mathrm{Ha}$. Sebagai akibat pelaksanaan putusan tersebut, telah terjadi pembongkaran rumah warga \pm 200 unit dan terdiri dari $343 \mathrm{KK}$, atau 1.411 jiwa. Eksekusi lanjutan dapat dikatakan berlangsung sukses karena mendapatkan pengawalan dari aparat TNI/POLRI sebanyak 1000 personil.
Eksekusi tersebut tidak hanya menyangkut 2 (dua) bidang tanah, namun telah mencapai luasan areal $\pm 18 \mathrm{Ha}$. Hal ini jelas tidak sesuai dengan batas-batas tanah yang tercantum dalam posita Gugatan Intervensi, yaitu seluas \pm 6 Ha. Upaya pembongkaran rumah warga \pm 200 unit dan terdiri dari $343 \mathrm{KK}$, atau 1.411 jiwa adalah dilakukan tanpa mengindahkan adanya Sertifikat Hak Milik warga yang tidak pernah dibatalkan oleh Putusan Pengadilan manapun. Demikian pula pihak yang menjadi korban dalam eksekusi tersebut (selain Para Tergugat Intervensi) adalah bukanlah pihak dalam perkara Gugatan Intervensi. Pihak korban eksekusi termaksud adalah tidak pernah menjalani proses persidangan guna pengujian hak pemilikannya, dengan kata lain pihak korban eksekusi termaksud tidak pernah mempunyai sengketa kepemilikan lahan dengan Penggugat Intervensi (Ahli Waris Salim Albakkar) di pengadilan.

Sehingganya, dengan adanya kasus tanah tersebut diperlukan terselenggaranya pendaftaran tanah untuk dengan mudah membuktikan haknya atas tanah yang dikuasainya, dan bagi para pihak yang berkepentingan, seperti calon pembeli dan calon penjual, untuk memperoleh keterangan yang diperlukan mengenai tanah yang menjadi objek perbuatan hukum yang akan dilakukan, serta bagi Pemerintah untuk melaksanakan kebijaksanaan pertanahan (Anatami, 2017). 


\subsection{Analisis Putusan Sengketa Tanah Lokasi} Tanjung Sari Kabupaten Banggai

Jika kita memperhadapkan objek sengketa dalam Perkara Perdata, Nomor: 02/PDT/G/1996/PN.Lwk, antara Pintung, Dkk Kuasa Hadin Lanusu sebagai Penggugat melawan Husen Taferokila sebagai Tergugat, dan ditindaklanjuti dengan adanya Gugatan Intervensi yang diajukan oleh Ahli Waris Salim Al Bakkar, telah menempatkan objek sengketa berupa 2 (dua) bidang tanah, yaitu :

\section{Bidang Pertama}

Berukuran Panjang 26,50 meter dan lebar 22 meter, dengan batas-batas:

- Utara dengan tanahnya Salim Al Bakkar/Wakaf;

- Timur dengan Pintung (Penggugat);

- Selatan dengan tanah Lawae;

- Barat dengan Jalan Raya Yos Sudarso; Bidang Kedua

Berukuran panjang 13,35 meter dan lebar 6,70 meter, dengan batas-batas:

- Utara dengan tanah Salim Albakkar I wakaf;

- Timur dengan rumah kediaman Pintung (Penggugat I) yang didirikan di atas tanah Penggugat;

- Selatan dengan tanah PenggugatPenggugat;

- Barat dengan tanah Objek Perkara;

Bahwa untuk meneguhkan hal pemilikan Ahli Waris Salim Al Bakkar atas 2 (dua) bidang tanah yang disengketakan sesuai Perkara
Perdata, Nomor 02/PDT/G/1996/ PN.Lwk, antara Pintung, Dkk Kuasa Hadin Lanusu sebagai Penggugat melawan Husen Taferokila sebagai Tergugat, maka Ahli Waris Salim Al Bakkar telah mendalilkan bahwa 2 (dua) bidang objek sengketa tersebut adalah merupakan bagian dari tanah milik Salim Al Bakkar / Ahli Waris Salim Al Bakkar (Penggugat Intervensi) seluas $\pm 6 \mathrm{Ha}$. Dalam proses pembuktiannya, ternyata Penggugat Intervensi (Ahli Waris Salim Al Bakkar dapat membuktikan bahwa objek sengketa berupa 2 (dua) bidang tanah tersebut adalah milik Salim Al Bakkar. Hal ini telah termuat dalam Putusan Pengadilan Negeri Luwuk, Nomor :02/Pdt.G/1996/PN.Lwk; Putusan Pengadilan Tinggi Sulawesi Tengah, Nomor : 81/PDT/1996/PT.Palu. Dengan demikian maka Putusan Pengadilan Negeri Luwuk serta Putusan Pengadilan Tinggi Palu adalah konsisten dalam melihat dan menempatkan objek sengketa a quo. Adapun dalil Penggugat Intervensi (Ahli Waris Salim Al Bakkar tentang pemilikan $\pm 6 \mathrm{Ha}$ tanah adalah merupakan rangkaian fakta untuk membuktikan pemilikan Penggugat Intervensi atas 2 (dua) bidang tanah objek sengketa.

Namun, jika kita perhadapkan substansi Putusan Pengadilan Negeri Luwuk, Putusan Pengadilan Tinggi Sulawesi Tengah dengan Putusan Mahkamah Agung, Nomor: 2351 K/Pdt./1997, tanggal 02 Juni 1999, dalam hal penetapan objek sengketa, maka terdapat perbedaan mendasar. Putusan Pengadilan Negeri Luwuk, Nomor :02/Pdt.G/1996/PN.Lwk; Putusan 
Pengadilan Tinggi Sulawesi Tengah, Nomor: 81/PDT/1996/PT.Palu telah menempatkan objek sengketa berupa 2 (dua) bidang tanah, sedangkan Putusan Mahkamah Agung, Nomor: 2351 K/Pdt./1997, tanggal 02 Juni 1999 telah menempatkan objek sengketa berupa hamparan tanah dengan batas-batas :

- Utara dahulu berbatasan dengan teluk Luwuk, sekarang berbatasan dengan tanah Pemerintah Daerah dan Kompleks Dolog;

- Timur, dahulu berbatasan dengan tanahnya Pr. Maasing dan Pr. Keling, sekarang berbatasan dengan tanah Lamusa;

- Selatan dahulu berbatasan dengan jurame, sekarang dengan jurang;

- Barat, berbatasan dengan kebunnya Pandan dan Hutan Lolaro;

Hal mana dengan menunjuk batas-batas tersebut maka bidang tanah termaksud sesuai dalil Gugatan Intervensi adalah seluas $\pm 6 \mathrm{Ha}$. Hal inilah yang menyebabkan terjadinya perbedaan penetapan objek sengketa antar putusan tersebut. Dapatlah dikatakan bahwa dari aspek kepastian objek sengketa sesuai Perkara Perdata, Nomor 02/PDT/G/1996/PN.Lwk, maka objek sengketa yang dimaksudkan dalam Putusan Mahkamah Agung, Nomor: 2351 K/Pdt./1997, tanggal 02 Juni 1999 adalah "melebihi" objek sengketa yang tercantum dalam Perkara Perdata, Nomor 02/PDT/G/1996/ PN.Lwk. Dengan kata lain, terdapat "ultra petita" dalam penetapan objek sengketa.
"Ultra petitanya" objek sengketa dalam Putusan Kasasi Mahkamah Agung tersebut, telah mengesampingkan segala hak milik pihak lain yang berada dalam areal $\pm 6 \mathrm{Ha}$, yang berdasarkan data yang ada terdapat \pm 50 buah Sertifikat Hak Milik yang tidak dibatalkan oleh putusan pengadilan manapun. Artinya bahwa Mahkamah Agung menyatakan $\pm 6 \mathrm{Ha}$ adalah milik Salim Al Bakkar in casu Berkah Al Bakkar, sedangkan Sertifikat Hak Milik pihak lain adalah berada dalam areal $\pm 6 \mathrm{Ha}$ tersebut. Adapun pemegang hak sesuai Sertifikat Hak Milik tidak pernah ditempatkan sebagai pihak dalam perkara perdata nomor: 02/PDT/G/1996/PN.Lwk.

Meskipun terdapat "ultra petita" dalam penetapan objek sengketa, namun terdapat amar "condemnatoir" dalam Putusan Kasasi Mahkamah Agung, yang perlu dikaji secara saksama guna menentukan objek eksekusi. Amar putusan tersebut adalah: "Menghukum Para Tergugat Intervensi untuk mengembalikan tanah sengketa, dalam keadaan kosong kepada Penggugat Intervensi". Berdasarkan amar Comdenatoir tersebut maka diketahui bahwa pihak-pihak yang dibebani kewajiban hukum untuk mengembalikan objek sengketa hanyalah Para Tergugat Intervensi, yang terdiri dari: 1. PINTUNG, 2. BAHRUN LANUSU, 3. HADIN LANUSU, 4. MASNIA LANUSU, 5. MIN LANUSU dan 6. HUSEN TAFEROKILA. Adapun objek sengketa yang wajib dikembalikan oleh Para Tergugat Intervensi adalah bidang tanah yang tengah dikuasai oleh Para Tergugat Intervensi. 
Berdasarkan pada diktum Condemnatoir tersebut maka telah tepat Penetapan Nomor: 01/Pen.Pdt/2008/PT.Sulteng, tanggal 21 Agustus 2008 yang menegaskan memerintahkan Ketua Pengadilan Negeri Luwuk untuk melanjutkan pelaksanaan Putusan Mahkamah Agung, Nomor: 2351 K/Pdt./1997, tanggal 02 Juni 1999 Jo. Putusan Peninjauan Kembali Nomor: 655 PK/Pdt/2000, tanggal 13 Oktober 2003, sepanjang mengenai 2 (dua) bidang tanah sebagaimana dimaksudkan dalam Perkara Perdata Nomor: 02/PDT/G/1996/PN.Lwk.

\subsection{Penyimpangan Eksekusi Putusan Sengekta Tanah Tanjung Sari Kabupaten Banggai}

Ketua Pengadilan Negeri Luwuk telah menetapkan objek eksekusi adalah meliputi lahan seluas $18 \mathrm{Ha}$, dimana terdapat \pm 70 Sertifikat Hak Milik milik warga masyarakat yang tidak pernah dibatalkan oleh putusan pengadilan manapun. Demikian pula pemegang hak sesuai Sertifikat Hak Milik tersebut tidak pernah ditempatkan sebagai pihak dalam perkara serta tidak memiliki sengketa tanah dengan Ahli Waris Salim Al Bakkar di Pengadilan Negeri Luwuk. Seharusnya Ketua Pengadilan Negeri Luwuk mempedomani Yurisprudensi Mahkamah Agung, Nomor: 3283 K/Pdt/1994, tanggal 27 Maret 1997, dengan kaidah hukum "Dengan tidak dibatalkannya sertifikat hak milik atas tanah, maka eksekusi terhadap tanah tersebut tidak dapat dilaksanakan".
Luas lahan yang dieksekusi adalah telah melewati lahan/tanah milik Salim Albakkar sebagaimana dikemukakannya dalam dalil Gugatan Intervensi yaitu seluas $\pm 6 \mathrm{Ha}$. Adapun dalil tentang luas tanah milik Salim Al Bakkar yaitu $\pm 6 \mathrm{Ha}$, adalah bukan dalam rangka penegasan hak milik, namun adalah bersifat rangkaian riwayat tanah untuk membuktikan bahwa 2 (dua) bidang tanah yang ditempatkan sebagai objek sengketa Perkara Perdata, Nomor: 02/Pdt/1996/PN.Lwk adalah milik Salim Al Bakkar. Dengan telah dilakukannya Eksekusi atas $\pm 18 \mathrm{Ha}$ tanah yang disertai dengan pembongkaran warga \pm 200 unit dan terdiri dari $343 \mathrm{KK}$, atau 1.411 jiwa, memperlihatkan bahwa proses eksekusi tersebut adalah tidak sejalan dengan diktum Condemnatoir dalam Putusan Mahkamah Agung, yang hanya menghukum Para Tergugat Intervensi untuk mengembalikan tanah sengketa kepada Penggugat Intervensi.

Ketua Pengadilan Negeri Luwuk telah tidak mempedomani Berita Acara Pemeriksaan Setempat tanggal 26 Agustus 2006. Bahwa atas permohonan Eksekusi yang diajukan oleh Kuasa Hukum Ahli Waris Salim Al Bakkar, maka Pengadilan Negeri Luwuk telah melakukan Pemeriksaan Setempat sebagaimana tertuang dalam Berita Acara Pemeriksaan Setempat tanggal 26 Agustus 2006. Sesuai keterangan mantan Jurusita Pengadilan Negeri Luwuk, Sdr. Suprioto Labelo, bahwa dalam Pemeriksaan Setempat tersebut pada batas sebelah Selatan tepat dirumah ko lu' (sekarang telah menjadi 
bangunan perkantoran DS-LNG dan telah dibongkar pada eksekusi Bulan Mei 2017), masih ditemukan pal batas tanah milik Salim Al Bakkar, dan itu dipedomasi saat Pemeriksaan Setempat. Adapun bidang tanah yang dieksekusi pada Bulan Mei 2017 telah melewati pal batas tersebut dan telah memasuki eks. Lahan milik Haka Usman. Seluruh bangunan yang berada di eks. Lahan Haka Usman telah dibongkar oleh Pengadilan Negeri Luwuk saat dilakukannya Eksekusi pada Bulan Mei 2017;

Hal lain pula, Ketua Pengadilan Negeri Luwuk telah menggunakan peta eksekusi yang dibuat secara sepihak oleh pemohon eksekusi, hal mana peta eksekusi tersebut telah dikesampingkan oleh Majelis Hakim dalam Perkara Perdata Nomor 22 / Pdt / 1977 (lihat Risalah Putusan No. 22/Pdt/1977) dan Ketua Pengadilan Negeri Luwuk telah mengesampingkan Putusan Mahkamah Agung Nomor 2031 /Sip/1980. Bahwa dalam Gugatan Intervensi terdapat pencantuman batas tanah sebelah Utara atas bidang tanah yang didalilkan sebagai milik Salim Al Bakkar, yaitu "dahulu Teluk Luwuk, sekarang berbatasan dengan Tanah Pemda / Kompleks Dolog. Adapun penetapan batas sebelah Utara ini adalah bersesuaian dengan batas tanah dalam Gugatan Nomor: 221 Pdt / 1977 yang diajukan oleh Penggugat: AHMAD BAKKAR (Ahli Waris Salim Al Bakkar). Bahwa sebagaimana diuraikan dalam Gugatan Perdata Nomor: 22/Pdt/1977 dan termuat dalam Putusan Pengadilan Negeri Luwuk, Nomor:
22/Pdt/1977 Jo. Putusan Mahkamah Agung, Nomor: 2031 /Sip/1980. Dalam Gugatan tersebut tegas dinyatakan bahwa bagian tanah pada sebelah utara telah diganti rugi oleh Pemerintah Kabupaten Banggai, dan uang ganti rugi tersebut telah di terima oleh Kapolres Banggai, Bapak Ardani Ali Tahun 1964, yang pada waktu itu berkedudukan juga sebagai Ketua Panitia Pembangunan Masjid Jami' Luwuk (Masjid Mutahidah). Diakui pula oleh Ahli Waris Salim Al Bakkar in casu AHMAD BAKKAR bahwa Ganti rugi tersebut telah digunakan untuk kepentingan Pembangunan Masjid Jami' (Masjid Mutahidah Luwuk. Pada faktanya, bahwa Ketua Pengadilan Negeri Luwuk telah menetapkan pula batas sebelah utara dalam hal ini tanah Pemerintah Kabupaten Banggai sebagai objek eksekusi, sehingga telah dilakukan pembongkaran atas bangunan yang berada pada kompleks Dolog, yang dalam Gugatan Intervensi telah tidak dimasukan sebagai lahan milik Salim Al Bakkar, justru telah ditetapkan sebagai batas tanah I lahan sebelah Utara.

Begitu banyak terdapat fakta pelanggaran pada saat Eksekusi Putusan Mahkamah Agung, Nomor: 2351 K/Pdt./1997, tanggal 02 Juni 1999 Jo. Putusan Peninjauan Kembali Nomor: 655 PK/Pdt/2000, tanggal 13 Oktober 2003, mendorong kami pada Lembaga PUSAT KAJIAN dan BANTUAN HUKUM FAKULTAS HUKUM UNIVERSITAS MUHAMMADIYAH LUWUK, untuk melaporkan kepada Komisi Yudisial untuk 
mendapatkan penanganan lebih lanjut guna penyelesaiannya.

Fakta lapangan menunjukkan bahwa Eksekusi atas $\pm 18 \mathrm{Ha}$ tanah yang disertai dengan pembongkaran rumah warga \pm 200 unit dan terdiri dari $343 \mathrm{KK}$, atau 1.411 jiwa, telah menimbulkan derita panjang warga masyarakat yang kehilangan tempat tinggal dan harta benda lainnya. Sementara itu sebagian warga masyarakat masih memiliki Sertifikat hak Milik atas tanah yang tidak pernah dinyatakan batal melalui putusan pengadilan manapun. Dari kajian yang telah kami lakukan sebagaimana diuraikan diatas memperlihatkan bahwa proses eksekusi tersebut adalah tidak sejalan dengan diktum Condemnatoir dalam Putusan Mahkamah Agung, yang hanya menghukum Para Tergugat Intervensi untuk mengembalikan tanah sengketa kepada Penggugat Intervensi.

\section{Kesimpulan}

Berdasarkan pembahasan yang telah diuraikan, kesimpulan kajian ini sebagai berikut, Pertama, Objek sengketa tanah di Lokasi Tanjung Sari Kabupaten Banggai berdasarkan Putusan Pengadilan Negeri Luwuk, Nomor :02/Pdt.G/1996/PN.Lwk, tanggal 9 Juli 1996 Jo. Putusan Pengadilan Tinggi Sulawesi Tengah, Nomor: 81/PDT/1996/PT.Palu, tanggal 15 Januari 1997, selain kedua putusan itu bersifat declaratoir. Kedua, Putusan Nomor 02/PDT/G/1996/PN.Lwk, dan Putusan Mahkamah Agung, Nomor: 2351 K/Pdt./1997, tanggal 02 Juni 1999 adalah "melebihi" objek sengketa dengan dalil gugatan intervensi yang menyebabkan terhjadinya objek sengketa antar putusan. Ketiga, telah terjadi penyimpangan proses eksekusi oleh Ketua Pengadilan Negeri Luwuk yang tidak sejalan dengan diktum Condemnatoir dalam Putusan Mahkamah Agung.

\section{DAFTAR PUSTAKA}

\section{Buku}

Harahap, Y. (2011). Hukum Acara Perdata. Jakarta : Sinar Grafik.

Rasyid, Raihan A. (1998). Hukum Acara Peradilan Agama. Jakarta : PT. Raja Grafindo Persada.

Winarta, Frans H, (1995). Advokat Indinesia, Citra, Idealisme, dan Keperhatinan. Jakarta : Sinar Harapan.

\section{J urnal}

Asikin, Z. (2014). Penyelesaian Konflik Pertanahan Pada Kawasan Pariwisata Lombok (Studi Kasus Tanah Terlantar Di Gili Trawangan Lombok, J urnal Dinamika Hukum, Vol.14 (No 2), pp.239-249, p.240.

Anatami, D. (2017). Tanggung Jawab Siapa, Bila Terjadi Sertifikat Ganda Atas Sebidang Tanah, J urnal Hukum Samudra Keadilan, Vol.12 (No.1), pp1-17, p.3.

Arisaputra, Muhammad I, (2013). Penerapan Prinsip-Prinsip Good Governance Dalam Penyelenggaraan Reforma Agraria Di Indonesia, Yuridika: Vol.28 (No.2), pp.188216, p.189. 
Jurnal Law Reform

Volume 14, Nomor 2, Tahun 2018

Djanggih, Hardianto dan Salle, (2017). Aspek

Hukum Pengadaan Tanah bagi Pelaksanaan Pembangunan untuk Kepentingan Umum, Pandecta: Research Law Journal, Vol.12 (No.2),pp, 165-172, p.166.

Hidayat, Rozi A. (2016). Analisis Yuridis Proses Pembatalan Sertifikat Hak Atas Tanah Pada Kawasan Hutan, Jurnal Kajian Hukum Dan Keadilan, Vol.4 (No. 2), pp, 8295, p.83.

Ismail, Ismaniar dan Rukmana S, Novayanti Sopia. (2017). Efektivitas Layanan Rakyat Untuk Sertifikasi Tanah (Larasita) Di Kota Makassar, J urnal Ilmiah Adminstrasi, Vol.8 (No.1).pp.20-38, p.21.

Listyawati, H. (2010). Kegagalan Pengendalian Alih Fungsi Tanah Dalam Perspektif Penatagunaan Tanah Di Indonesia, J urnal Mimbar Hukum, Vol.22 (No.1), pp.37-57, p.37.

Panget, Ardiles E. (2013), Penyelesaian Hak Atas Tanah Yang Memiliki Sertifikat Hak Milik Ganda, Lex Administratum, Vol.1 (No.3).pp, 42-45, p.42.

Pangemanan, E. (2013), Upaya Penyelesaian Sengketa Kepemilikan Hak Atas Tanah, Lex Privatum, Vol.1 (No.4), pp.57-66, p.57. Permatasari, Elfira., Adjie, Habib., \& Djanggih, Hardianto. (2018). Perlindungan Hukum Kepemilikan Tanah Absentee yang
Program Studi Magister Ilmu Hukum Fakultas Hukum Universitas Diponegoro

Diperoleh Akibat Pewarisan, Jurnal Varia J usticia, Vol.4 (No.1).pp, 1-9, p.1.

Wowor, Fingli A. (2014). Fungsi Badan Pertanahan Nasional Terhadap Penyelesaian Sengketa Tanah, Lex Privatum, Vol.2 (No.2).pp.95-104, p.97. 